\title{
Norepinephrine release may play a critical role in the Warburg effect: an integrative model of tumorigenesis
}

\author{
Minireview \\ P. J. FITZGERALD \\ Department of Psychiatry, University of Michigan, Ann Arbor, MI, USA \\ *Correspondence: pfitz1940@gmail.com
}

Received April 22, 2020 / Accepted May 19, 2020

\begin{abstract}
Many cancer cells share the property of carrying out markedly elevated rates of glycolysis to generate energy even in the presence of sufficient oxygen, and this is known as the Warburg effect. In recent years, there has been a resurgence of interest in the Warburg effect, as the field of oncology has amassed evidence that cellular metabolism may play a prominent role in many neoplasms. Largely in the past decade, another prominent and perhaps surprising factor has emerged in the cancer literature: the catecholamine molecules, epinephrine (adrenaline) and norepinephrine (noradrenaline), appear to play a role in tumorigenesis and metastasis. The drug propranolol, which blocks beta-adrenergic receptors, may be therapeutic in human angiosarcoma, melanoma, and ovarian cancer. The current paper synthesizes these older and more recent findings, in an attempt to unify the major factors that contribute to tumorigenesis. This paper suggests that in addition to the direct interaction of catecholamine signaling with genetic risk factors (including mutagenesis), it interacts with environmental factors such as hypertension, obesity, unhealthy dietary components, physical inactivity, substance abuse, and mental or emotional stress, to promote the Warburg effect by facilitating glucose availability through suppression of pancreatic insulin release. Further, it proposes that many cancer cells synthesize and release catecholamines to activate their own receptors in an autocrine fashion. In summary, catecholamines are an important "new" factor in cancer that may interface with both genetics and environmental factors to alter the Warburg effect and modulate tumorigenesis.
\end{abstract}

Key words: beta-blocker, microenvironment, prazosin, pancreas, clonidine, guanfacine, genetics

Eminent German biochemist Otto Heinrich Warburg, who won the Nobel Prize in Physiology or Medicine in 1931 and made a wide range of seminal discoveries in his field, conducted experiments in the 1920s that led him to conclude that many if not all types of cancerous cells carry out a markedly elevated level of glycolysis [1-4]. This pattern of metabolism is puzzling because many cancer cells have adequate levels of oxygen to generate energy through the much more efficient process known as oxidative phosphorylation, which relies on intact mitochondria [5]. This metabolic phenomenon has been termed "aerobic glycolysis", and it later became known as the Warburg effect $[5,6]$. It is now known that some cancerous cells do not show elevated glycolysis, but the majority of cells do appear to exhibit this effect, and it has been suggested that blocking it could have anti-cancer effects [7].
The last several decades of research in oncology have been dominated by genetic and epigenetic models [8-12], but in recent years there has been a resurgence of interest in cellular metabolism in cancer, including the Warburg effect [13-15]. This is evident in research into the intracellular molecular mechanisms by which glucose is processed to contribute to the effect $[16,17]$. Additionally, the diabetes drug metformin, which downregulates glucose signaling, is now being widely studied for its potentially therapeutic effects in various malignancies [18-20].

In the past decade or so, another signaling pathway has gained traction in the oncology literature: the sympatheticadrenomedullary system comprising epinephrine (EPI; also known as adrenaline) and norepinephrine (NE; noradrenaline) [21-24], where these two catecholamines function as adrenal and sympathetic nervous system stress hormones 
in the "fight-or-flight" response to environmental stressors or dangers [25-27]. NE in particular is an important neurotransmitter in the brain and at the output of the sympathetic nervous system, which comprises the set of peripheral nerves that regulate organs throughout the body. In an apparently serendipitous discovery around 2008, a group of French doctors published a paper suggesting the drug propranolol, which blocks beta-adrenoceptors (i.e., receptors that EPI and NE activate), can be used to shrink or eliminate benign tumors called infantile hemangiomas in newborns [28]. Since then a number of scientific papers have been published on this topic, and propranolol has become the first-line treatment for these tumors, clinically $[29,30]$.

Meanwhile, mainly within the past decade or so, a number of studies have suggested that propranolol is therapeutic in a range of cancer types (counteracting both tumorigenesis and metastasis, including in combination with other pharmacological agents), using in vitro preparations, in vivo rodent models, and retrospective epidemiological studies of human subjects [23, 31-34]. A fairly recent, prominent retrospective study found that non-selective beta-blocker (such as propranolol) use in women with ovarian cancer was associated with a median overall survival of 94.9 months, whereas non-users survived 42 months [35]. A prospective human subjects study found that propranolol protects individuals with thick cutaneous melanoma from disease recurrence [36].
A number of preclinical and clinical studies now also suggest favorable effects of propranolol on angiosarcoma, a difficult to treat malignancy with a poor prognosis [37-41]. There are also a number of ongoing clinical trials for propranolol in a variety of other neoplasms. Additional studies have suggested that NE itself promotes cancer [24, 42], and drugs other than propranolol that likewise block adrenoceptors, such as prazosin (which blocks the alphal adrenoceptor), are also therapeutic in rodent models [43]. Prazosin is already being used clinically to treat benign prostatic hyperplasia [44]. An additional point is that the molecules - serotonin, acetylcholine, and melatonin - may act centrally or interact with the sympathetic-adrenomedullary system in the periphery to modulate tumorigenesis and metastasis [45-47].

The rest of this paper integrates information about the Warburg effect and the "new" findings on sympatheticadrenomedullary signaling, with the more well-established data on genetics and epigenetics in cancer. This framework also includes the following major environmental risk factors (which may additionally have a genetic component) for a broad range of neoplasms: hypertension, obesity (and associated dietary factors), physical inactivity, substance abuse, and (somewhat controversially) mental or emotional stress. I am suggesting here that elevated (partially genetic) sympathetic-adrenomedullary signaling plays a significant role in the development or manifestation of these risk factors, and



Figure 1. Proposed factors that contribute to tumorigenesis. In addition to the direct interaction of elevated central catecholamine release or peripheral sympathetic-adrenomedullary signaling with epigenetic and genetic risk factors (including mutagenesis), epinephrine (EPI) and norepinephrine (NE) interact with environmentally-regulated factors such as hypertension, obesity, unhealthy dietary components, physical inactivity, substance abuse, and mental or emotional stress, to promote the Warburg effect by facilitating glucose availability systemically through suppression of pancreatic insulin release (and perhaps by increasing insulin resistance). Further, this paper proposes that many cancer cells synthesize and release catecholamine molecules to activate their own alpha (a) and beta $(\beta)$ adrenergic receptors in an autocrine fashion. EPI and NE may also interact with immune function, systemic inflammation, and oxidative stress to promote tumorigenesis and metastasis. 
in doing so may play a critical role in the Warburg effect by promoting glycolysis, largely by helping supply glucose to the cancerous cells via suppression of insulin release by the pancreas. Those risk factors may in turn promote elevated sympathetic-adrenomedullary signaling.

Thus, in this model (Figure 1), cancer originates through a combination of genetic, epigenetic, and environmental factors over many years, usually including elevated sympathetic-adrenomedullary signaling throughout the process. (NE is also capable of causing mutations in DNA, further associating sympathetic-adrenomedullary signaling with the genetic component of cancer $[48,49])$. Through these genetic and environmental factors, cancer cells may begin to selectively use glycolysis to fuel their growth and replication, and may also use glucose to help synthesize their own NE and EPI, which they release locally to stimulate their extracellular adrenoceptors in an autocrine fashion, thereby modulating the tumor microenvironment. This elevated sympatheticadrenomedullary signaling, in turn, maintains or accentuates high levels of signaling in intracellular pathways that are already upregulated (and have previously been widely implicated in various neoplasms), such as Ras/MAPK, PI3K/Akt, and JAK/STAT, that fuel abnormal replication [50-53]. Thus, systemically elevated sympathetic-adrenomedullary signaling - that has existed chronically through genetic, epigenetic, and environmental mechanisms - may be complemented by additional cellular autocrine release. The rest of the paper briefly provides more detail on each of the components of the theory, integrating them with sympathetic-adrenomedullary signaling and the Warburg effect.

\section{Genetics and epigenetics}

For the last several decades, oncology research has focused on genetic mutations (or environmental phenomena that drive them) as the principal etiological factor in a broad range of cancer types [8-10]. For example, pioneering studies have identified a number of key oncogenes and tumor suppressor genes, that when mutated can help lead to tumorigenesis [54]. A potential connection of this literature with elevated sympathetic-adrenomedullary signaling is that NE and EPI themselves are able to induce DNA structural damage in a number of studies. For example, EPI and NE caused DNA damage in embryonic pluripotent cells via beta2 adrenoceptors [49], and NE also damaged DNA in human mammary epithelial MCF-10A cells [48]. Mental or emotional stress can also promote DNA damage, possibly by acting through NE [55]. I am not suggesting that NE (or EPI) is the main factor in mutagenesis, but rather that it is an important factor to consider, although most cancer-inducing mutations probably arise spontaneously or through other means. Also of note is that many of the mutated molecular pathways that can promote cancer - such as Ras/MAPK, PI3K/Akt, and JAK/STAT - have also been shown to be activated when NE or EPI bind to their G-protein-coupled receptors (i.e., adrenoceptors) on the exterior (i.e., extracellular) surface of cells [50-53]. Thus, NE/EPI signaling and mutations arising from various means interact with the same molecular, protein-based pathways inside of the cancer cell, further reinforcing the idea that mutations as well as sympathetic-adrenomedullary signaling need to be considered in tumorigenesis. Another point of interest is that epigenetic mechanisms in cancer may also interface with sympatheticadrenomedullary signaling: the histone deacetylase (HDAC) inhibitor drug, vorinostat, which modulates transcription of a number of genes, has been shown to increase cellular expression of the NE transporter (NET) molecule in the synapse [56]. Vorinostat and other HDAC inhibitors, such as valproic acid, are already being used clinically to treat subtypes of cancer $[57,58]$, and their principal therapeutic mechanism may be that by increasing expression of NET, they reduce the extracellular level of NE.

The genetics of the sympathetic-adrenomedullary system itself, independent of any mutations, may also play a prominent role in tumorigenesis and metastasis, perhaps in large part by facilitating the above three molecular pathways through signaling via adrenoceptors. Polymorphisms in the various genes comprising beta-adrenergic signaling could facilitate cancer by increasing the tone (i.e., overall chronic activation) of this system, while also amplifying ongoing acute responses to mental or emotional stress. A number of studies have already implicated beta-adrenergic genes in various malignancies, including interaction with environmental or other risk factors [59-62]. Polymorphisms in adrenoceptors, as well as the NE-synthesizing enzyme dopamine beta-hydroxylase, can modulate insulin resistance and alter glucose signaling [63-66], and may thereby influence the Warburg effect.

\section{Hypertension}

A number of studies, including epidemiological analyses as well as rodent data, suggest that hypertension (i.e., high blood pressure) is a risk factor for developing a number of types of neoplasms, although this is a controversial topic [67]. For example, spontaneously hypertensive rats (SHR) exhibited heightened sensitivity to the carcinogen, methylcholanthrene (MCA), which may be mediated in part by age-related deficits in $\mathrm{T}$ cell functioning, as well as elevated natural killer cell activity [68]. SHR also exhibited a greater frequency of chromosomal aberrations upon exposure to 7,12-dimethylbenz[a]-anthracene (DMBA) than control Wistar Kyoto rats [69]. Regarding human subjects data, a meta-analysis found a weak, albeit statistically significant, elevation in prostate cancer risk in men with hypertension [70]. A retrospective cohort study of Taiwanese subjects found that hypertension was associated with elevated rates of renal and uterine corpus cancers [71]. This ties in with a large body of evidence, including genetic and physiological studies, implicating elevated sympathetic-adrenomedullary signaling 
in high blood pressure [72, 73]. For example, polymorphisms of beta-adrenoceptor genes are associated with hypertension [74], and SHR are known to exhibit elevated plasma NE [75]. Moreover, drugs that interfere with sympathetic-adrenomedullary signaling such as clonidine, propranolol, and prazosin, have long been used to treat high blood pressure clinically [76]. Thus, one possibility is that hypertension is a factor in various malignancies through elevated sympathetic-adrenomedullary signaling and its associated molecular processes [21], where this elevation may facilitate glucose signaling to enhance the Warburg effect, through suppression of insulin release by the pancreas as described below.

\section{Obesity and metabolic syndrome}

Being markedly overweight is also a risk factor for a number of cancer types. For example, obesity is associated with elevated risk or aggressiveness of colorectal [77], prostate [78], and breast [79] neoplasms. As for hypertension, there is an extensive literature, both in human subjects and animal models, linking obesity with elevated sympathetic-adrenomedullary signaling $[80,81]$. For example, in healthy men, beta 2 adrenoceptor polymorphisms associated with heightened sympathetic nervous system activity may predict future onset of obesity [82]. Rats fed a diet enriched in lard for four weeks exhibited $61 \%$ higher plasma NE relative to control animals fed regular chow [83]. Not surprisingly, there is also a known association between obesity and hypertension, and the two conditions coexist in many cases of metabolic syndrome, which itself is a major public health concern [84]. Metabolic syndrome is widely believed to be characterized by elevated sympathetic nervous system activity, further implicating sympathetic-adrenomedullary signaling in its pathophysiology [85]. Since one of the hallmarks of metabolic syndrome is insulin resistance, the disorder is further associated with elevated plasma glucose levels (since insulin, which is secreted by the pancreas, lowers blood glucose levels) [84, 86]. There are a number of physiological studies demonstrating that EPI suppresses insulin release from pancreatic beta cells [87]. Thus, hypertension, obesity, and also the often resulting condition of metabolic syndrome, are associated with elevated sympathetic-adrenomedullary signaling that raises systemic glucose levels and could thereby promote the Warburg effect in a number of organ systems and cell types throughout the body.

\section{Dietary factors}

Particular dietary factors, such as increased consumption of simple carbohydrates or foods high in saturated fat, could directly or indirectly boost glucose signaling to facilitate the Warburg effect, and chronically contribute to obesity and metabolic syndrome as well [88]. Significant consumption of high sucrose foods is associated with greater risk of colon [89], breast [90], lung [91], pancreatic [92], and endometrial
[93] cancer. Consumption of dietary sucrose is also associated with elevated noradrenergic and sympathetic-adrenomedullary signaling, both in human subjects and in rodents [94-96]. A high-fat diet also confers greater risk of colon [97, 98], breast [99], and prostate [100] neoplasms. This dietary factor is associated with elevated noradrenergic turnover and augmented sympathetic activity as well [83, 101, 102]. Finally, high sodium intake is associated in males with a greater risk of colorectal [103] and gastric [104] cancer; it likewise boosts plasma NE in spontaneously hypertensive rats [105] and can do the same in salt-sensitive human subjects [106]. In summary, dietary intake of significant amounts of sucrose, fats, and sodium confers greater risk for a number of cancer types, while also being associated with elevated noradrenergic signaling and sympathetic-adrenomedullary activation. Whereas intake of sucrose, which is a disaccharide consisting of a glucose and a fructose molecule, can directly boost glucose signaling to contribute to the Warburg effect, high fat or sodium intake (as well as sucrose consumption) boosts sympathetic-adrenomedullary signaling and could thereby indirectly contribute, possibly through pancreatic beta-cell modulation of insulin release.

\section{Physical exercise}

An adequate amount of physical exercise, perhaps aerobic exercise in particular, is associated with a number of health benefits, including a reduction in cancer risk, as well as improved survival in existing cases of cancer. For example, engaging in recreational physical activity is associated with a reduction in risk for breast [107, 108], colorectal [108], and lung [109] cancer. A number of studies suggest that exercise acutely boosts sympathetic-adrenomedullary signaling [110, 111]. Some studies suggest that repeated exercise, carried out over for example a number of weeks or months, suppresses sympathetic-adrenomedullary signaling both in animal models [112-115] and in humans [116], which is a possible mechanism for the reduced risk of developing or recurrence of cancer. Repeated exercise may also help counteract hypertension, obesity, metabolic syndrome, and insulin resistance - entities that may all be characterized by elevated sympathetic-adrenomedullary signaling - and may thereby reduce glucose signaling and oppose the Warburg effect.

\section{Substance abuse}

Substance abuse, particularly alcohol abuse and cigarette smoking, is associated with an increased risk of a number of cancer types, not limited to liver and lung neoplasms, respectively [117-119]. Although the molecular mechanisms underlying this effect on cancer risk are not well established, a broad range of substances of abuse, including alcohol and nicotine, acutely boost brain noradrenergic signaling (for review, see reference [120]). In the long-term, substance abuse may also be associated with chronically elevated 
noradrenergic signaling, both in the brain and the periphery [120]. Hence, substance abuse represents another means through which increased central noradrenergic or sympathetic-adrenomedullary signaling may promote tumorigenesis, including through facilitation of glucose signaling.

\section{Mental or emotional stress}

Whether exposure to marked mental or emotional stress or trauma promotes cancer is a controversial topic. For example, a recent, large epidemiological study of breast cancer in Great Britain found only mixed evidence with regard to an increase in cancer risk [121], whereas three recent studies support a role for stress in breast cancer [122-124]. A recent metaanalysis of English and Scottish studies found that mental or emotional distress is a predictor of mortality in a variety of neoplasms [125]. Further, a Canadian epidemiological study found that men who reported higher levels of perceived stress in the workplace across a lifetime were at greater risk for neoplasms at five major sites of the body [126]. Data from rodent models provide strong evidence that mental or emotional stress promotes tumorigenesis and worsens overall survival [127, 128]. For example, Adamekova et al. found in female rats that seven consecutive days (120 min per day) immobilization stress, applied within the initiation phase of chemically-induced carcinogenesis, had a remarkable stimulatory effect on evaluated parameters in a breast carcinoma model. They found a marked $153 \%$ increase in tumor frequency per group, a 57\% increase in tumor incidence, and a shortened latency period by seven days, all of which were statistically significant compared to controls [129].

As stated earlier, NE and EPI are "stress hormones" that are known to be released from cells, in the brain and the peripheral adrenal glands (as well as the sympathetic nervous system), as part of the fight-or-flight response to environmental threats or other aversive situations. Thus, exposure to trauma or marked mental or emotional stress, perhaps especially when such exposure is ongoing and chronic, may be another avenue through which elevated central or sympathetic-adrenomedullary signaling has deleterious effects on cancer onset, progression, or recurrence, perhaps in part by suppressing insulin production and promoting the Warburg effect.

\section{Synthesis and autocrine release of NE and EPI}

Another aspect of the overall hypothesis put forth in this paper is that many (but probably not all) cancer cells may synthesize their own pools of NE and EPI. One possibility is that such biosynthesis is facilitated by the increased availability of glucose. While biosynthesis of NE and EPI has historically been primarily localized to neurons in particular brainstem nuclei, cells in the adrenal glands, and sympathetic nerve endings, there are some data supporting catecholamine biosynthesis in other cell types, including immune cells [130,
131]. There are also findings from Schuller and colleagues that certain pancreatic and lung cancer cells synthesize their own $\mathrm{NE}$, and then release it locally to stimulate their own extracellular adrenoceptors in an autocrine manner $[132,133]$ that modulates the tumor microenvironment. I am suggesting here that such a "self-stimulation loop" may be present in a wide range of cancer types, and it promotes signaling in already upregulated molecular pathways - such as Ras/ MAPK, PI3K/Akt, and JAK/STAT - through adrenoceptor activation that sustains and facilitates further tumorigenesis and metastasis. One possibility is that NE increases glucose availability in the tumor microenvironment and beyond, and glucose availability may increase NE production in cancerous cells and possibly systemically, thereby potentially setting up a positive feedback loop that may be critical for tumorigenesis, growth, and metastasis. A recent osteosarcoma study found that NE is elevated in the tumor microenvironment relative to the adjacent and non-oncological bone, as are betaadrenoceptors and the enzyme dopamine beta-hydroxylase which synthesizes NE [134]. A related point on the tumor microenvironment: viral-based cancers [135] may interact with local NE to promote tumorigenesis and metastasis.

\section{Propranolol}

There is increasing interest in using the non-selective betaadrenoceptor (beta1 and beta2) blocking drug, propranolol, to prevent or treat various malignancies in human subjects $[31,41]$. Cancer cells, in a given case, however, need not manufacture their own NE/EPI nor release it in an autocrine fashion to be susceptible to propranolol treatment, since this drug or related ones (carvedilol, nebivolol) may help lower blood sugar via modulation of insulin release by the pancreas or increasing insulin sensitivity $[136,137]$. Propranolol and related beta-blockers may also improve glycemic control through modulation of GLUT4 glucose transporter expression and hexokinase-2, including in breast cancer cells [138-140]. In this scenario, propranolol could also block beta-adrenoceptors on the extracellular surface of the cancer cells, where these receptors would be responding to NE/EPI from others (i.e., non-autocrine) sources such as the adrenal glands. Cancer cells, in addition, need not exhibit the Warburg effect to be susceptible to propranolol (or related drugs): the drug could still block beta-adrenoceptors on the surface of these cells and thereby dampen intracellular molecular pathways associated with cancer. Also, if cancer cells exhibit the Warburg effect but do not have adrenoceptors, in a given case, they could still be susceptible to propranolol because this drug or related ones could still lower blood glucose via the pancreas or increase insulin sensitivity.

\section{Summary and conclusions}

As reviewed above, a wide range of genetic, epigenetic, and environmental factors may interact with central and 
sympathetic-adrenomedullary pathways to modulate glucose signaling and thereby influence tumorigenesis and metastasis via the Warburg effect. Hypertension, obesity (and by extension, unhealthy dietary factors), physical inactivity, substance abuse, and recurrent mental or emotional stress - which may all be associated with chronically elevated sympathetic-adrenomedullary signaling - could promote cancer not only through the catecholaminergic lowering of insulin release (via pancreatic beta cells) or sensitivity to enhance systemic glucose signaling but also by NE and EPI binding to and activating adrenoceptors directly on cancer cells. Catecholaminergic autocrine signaling by cancer cells themselves may complement, in some individuals, already genetically elevated sympathetic-adrenomedullary tone that is present throughout the body and may also interact with the above environmental factors to promote malignancies. The beta-blocking drug propranolol already shows promising effects in a wide range of cancer types in human subjects, and other drugs that may lower catecholamine release or transmission - clonidine, guanfacine, dexmedetomidine, for example - should also be investigated in greater detail for their potentially therapeutic effects. The glucose modulating drug, metformin, which has been used clinically for years to treat diabetes, is gaining further traction for use in various neoplasms $[18,141]$, including in combination with propranolol [142]. Perhaps propranolol, metformin, and related catecholamine or glucose-modulating agents may not only attenuate the Warburg effect $[143,144]$ but also synergize with existing or emerging agents, such as in metronomic chemotherapy [39] or immunotherapy [145], to improve clinical outcomes.

\section{References}

[1] WARBURG O. Versuche an überlebendem CarcinomGewebe (Methoden). Biochem Zeitschr 1923; 142: 317-333.

[2] WARBURG O. Über den heutigen Stand des Carcinomproblems. Naturwissenschaften 1927; 15: 1-4.

[3] WARBURG O, POSENER K, NEGELEIN E. Über den Stoffwechsel der Carcinomzelle. Biochem Zeitschr 1924; 152: 309-344.

[4] WARBURG O, WIND F, NEGELEIN E. The metabolism of tumors in the body. J Gen Physiol 1927; 8: 519-530. https:// doi.org/10.1085/jgp.8.6.519

[5] KOPPENOL WH, BOUNDS PL, DANG CV. Otto Warburg's contributions to current concepts of cancer metabolism. Nat Rev Cancer 2011; 11: 325-337. https://doi.org/10.1038/ $\operatorname{nrc} 3038$

[6] RACKER E. Bioenergetics and the problem of tumor growth. Am Sci 1972; 60: 56-63.

[7] PELICANO H, MARTIN DS, XU RH, HUANG P. Glycolysis inhibition for anticancer treatment. Oncogene 2006; 25: 4633-4646. https://doi.org/10.1038/sj.onc.1209597

[8] VOGELSTEIN B, KINZLER KW. Cancer genes and the pathways they control. Nat Med 2004; 10: 789-799. https:// doi.org/10.1038/nm1087
[9] ROBSON M, OFFIT K. Inherited predisposition to cancer: introduction and overview. Hematol Oncol Clin North Am 2010; 24: 793-797. https://doi.org/10.1016/j.hoc.2010.06.005

[10] MATHEWS CK. Deoxyribonucleotide metabolism, mutagenesis and cancer. Nat Rev Cancer 2015; 15: 528-539. https://doi.org/10.1038/nrc3981

[11] KGATLE MM, KALLA AA, ISLAM MM, SATHEKGE M, MOORAD R. Prostate Cancer: Epigenetic Alterations, Risk Factors, and Therapy. Prostate Cancer 2016; 2016: 5653862. https://doi.org/10.1155/2016/5653862

[12] LI HT, DUYMICH CE, WEISENBERGER DJ, LIANG G. Genetic and epigenetic alterations in bladder cancer. Int Neurourol J 2016; 20: S84-94. https://doi.org/10.5213/ inj. 1632752.376

[13] POTTER M, NEWPORT E, MORTEN KJ. The Warburg effect: 80 years on. Biochem Soc Trans 2016; 44: 1499-1505. https://doi.org/10.1042/BST20160094

[14] VILLA E, RICCI JE. How does metabolisms affect cell death in cancer? FEBS J 2016; 283: 2653-2660. https://doi. org/10.1111/febs. 13570

[15] GWANGWA MV, JOUBERT AM, VISAGIE MH. Crosstalk between the Warburg effect, redox regulation and autophagy induction in tumourigenesis. Cell Mol Biol Lett 2018; 23: 20. https://doi.org/10.1186/s11658-018-0088-y

[16] LIS P, DYLAG M, NIEDZWIECKA K, KO YH, PEDERSEN $\mathrm{PL}$ et al. The HK2 dependent "Warburg effect" and mitochondrial oxidative phosphorylation in cancer: Targets for effective therapy with 3-bromopyruvate. Molecules 2016; 21: 1730. https://doi.org/10.3390/molecules 21121730

[17] LI Y, LI X, KAN Q, ZHANG M, LI X et al. Mitochondrial pyruvate carrier function is negatively linked to Warburg phenotype in vitro and malignant features in esophageal squamous cell carcinomas. Oncotarget 2017; 8: 1058-1073. https://doi.org/10.18632/oncotarget.13717

[18] YU X, MAO W, ZHAI Y, TONG C, LIU M et al. Anti-tumor activity of metformin: from metabolic and epigenetic perspectives. Oncotarget 2017; 8: 5619-5628. https://doi. org/10.18632/oncotarget.13639

[19] AMARAL MEA, NERY LR, LEITE CE, DE AZEVEDO WF JR, CAMPOS MM. Pre-clinical effects of metformin and aspirin on the cell lines of different breast cancer subtypes. Invest New Drugs 2018; 36: 782-796. https://doi.org/10.1007/ s10637-018-0568-y

[20] LI P, ZHANG C, GAO P, CHEN X, MA B et al. Metformin use and its effect on gastric cancer in patients with type 2 diabetes: A systematic review of observational studies. Oncol Lett 2018; 15: 1191-1199. https://doi.org/10.3892/ ol.2017.7370

[21] FITZGERALD PJ. Is norepinephrine an etiological factor in some types of cancer? Int J Cancer 2009; 124: 257-263. https://doi.org/10.1002/ijc. 24063

[22] FITZGERALD PJ. Testing whether drugs that weaken norepinephrine signaling prevent or treat various types of cancer. Clin Epidemiol 2010; 2: 1-3. https://doi.org/10.2147/ CLEP.S8903

[23] FITZGERALD PJ. Beta blockers, norepinephrine, and cancer: An epidemiological viewpoint. Clin Epidemiol 2012; 4: 151-156. https://doi.org/10.2147/CLEP.S33695 
[24] KRIZANOVA O, BABULA P, PACAK K. Stress, catecholaminergic system and cancer. Stress 2016; 19: 419-428. https://doi.org/10.1080/10253890.2016.1203415

[25] KOPIN IJ. Definitions of stress and sympathetic neuronal responses. Ann N Y Acad Sci 1995; 771: 19-30. https://doi. org/10.1111/j.1749-6632.1995.tb44667.x

[26] JEZOVA D, JURANKOVA E, MOSNAROVA A, KRISKA M, SKULTETYOVA I. Neuroendocrine response during stress with relation to gender differences. Acta Neurobiol Exp (Wars) 1996; 56: 779-785.

[27] GOLDSTEIN DS, KOPIN IJ. Adrenomedullary, adrenocortical, and sympathoneural responses to stressors: a metaanalysis. Endocr Regul 2008; 42: 111-119.

[28] LEAUTE-LABREZE C, DUMAS DE LA ROQUE E, HUBICHE T, BORALEVI F, THAMBO JB et al. Propranolol for severe hemangiomas of infancy. N Engl J Med 2008; 358: 2649-2651. https://doi.org/10.1056/NEJMc0708819

[29] CASTANEDA S, MELENDEZ-LOPEZ S, GARCIA E, DE LA CRUZ H, SANCHEZ-PALACIO J. The role of the pharmacist in the treatment of patients with infantile hemangioma using propranolol. Adv Ther 2016; 33: 1831-1839. https://doi.org/10.1007/s12325-016-0391-9

[30] POLITES SF, WATANABE M, CRAFTON T, JENKINS TM, ALVAREZ-ALLENDE CR et al. Surgical resection of infantile hemangiomas following medical treatment with propranolol versus corticosteroids. J Pediatr Surg 2019; 54: 740-743. https://doi.org/10.1016/j.jpedsurg.2018.08.001

[31] AKBAR S, ALSHARIDAH MS. Are beta blockers new potential anticancer agents? Asian Pac J Cancer Prev 2014; 15: 9567-9574. https://doi.org/10.7314/apjcp.2014.15.22.9567

[32] WEI WJ, SHEN CT, SONG HJ, QIU ZL, LUO QY. Propranolol sensitizes thyroid cancer cells to cytotoxic effect of vemurafenib. Oncol Rep 2016; 36: 1576-1584. https://doi. org/10.3892/or.2016.4918

[33] ZHOU C, CHEN X, ZENG W, PENG C, HUANG G et al. Propranolol induced G0/G1/S phase arrest and apoptosis in melanoma cells via AKT/MAPK pathway. Oncotarget 2016; 7: 68314-68327. https://doi.org/10.18632/oncotarget.11599

[34] POWE DG, VOSS MJ, ZANKER KS, HABASHY HO, GREEN AR et al. Beta-blocker drug therapy reduces secondary cancer formation in breast cancer and improves cancer specific survival. Oncotarget 2010; 1: 628-638. https://doi. org/10.18632/oncotarget.101009

[35] WATKINS JL, THAKER PH, NICK AM, RAMONDETTA LM, KUMAR S et al. Clinical impact of selective and nonselective beta-blockers on survival in patients with ovarian cancer. Cancer 2015; 121: 3444-3451. https://doi.org/10.1002/ cncr.29392

[36] DE GIORGI V, GRAZZINI M, BENEMEI S, MARCHIONNI N, BOTTERI E et al. Propranolol for off-label treatment of patients with melanoma: results from a cohort study. JAMA Oncol 2018; 4: e172908. https://doi.org/10.1001/jamaoncol.2017.2908

[37] CHISHOLM KM, CHANG KW, TRUONG MT, KWOK S, WEST RB et al. $\beta$-Adrenergic receptor expression in vascular tumors. Mod Pathol 2012; 25: 1446-1451. https://doi. org/10.1038/modpathol.2012.108
[38] STILES JM, AMAYA C, RAINS S, DIAZ D, PHAM R et al. Targeting of beta adrenergic receptors results in therapeutic efficacy against models of hemangioendothelioma and angiosarcoma. PLoS One 2013; 8: e60021. https://doi. org/10.1371/journal.pone.0060021

[39] BANAVALI S, PASQUIER E, ANDRE N. Targeted therapy with propranolol and metronomic chemotherapy combination: sustained complete response of a relapsing metastatic angiosarcoma. Ecancermedicalscience 2015; 9: 499. https:// doi.org/10.3332/ecancer.2015.499

[40] CHOW W, AMAYA CN, RAINS S, CHOW M, DICKER$S O N$ EB et al. Growth attenuation of cutaneous angiosarcoma with propranolol-mediated $\beta$-blockade. JAMA Dermatol 2015; 151: 1226-1229. https://doi.org/10.1001/jamadermatol.2015.2554

[41] GALVAN CD, AYYAPPAN AP, BRYAN BA. Regression of primary cardiac angiosarcoma and metastatic nodules following propranolol as a single agent treatment. Oncoscience 2018; 5: 264-268. https://doi.org/10.18632/oncoscience. 472

[42] BARBIERI A, BIMONTE S, PALMA G, LUCIANO A, REA D et al. The stress hormone norepinephrine increases migration of prostate cancer cells in vitro and in vivo. Int J Oncol 2015; 47: 527-534. https://doi.org/10.3892/ ijo. 2015.3038

[43] LIN SC, CHUEH SC, HSIAO CJ, LI TK, CHEN TH et al. Prazosin displays anticancer activity against human prostate cancers: targeting DNA and cell cycle. Neoplasia 2007; 9: 830-839. https://doi.org/10.1593/neo.07475

[44] MATHUR RP, NAYAK S, SIVARAMAKRISHNAN R, JAIN V. Role of alpha blockers in hypertension with benign prostatic hyperplasia. J Assoc Physicians India 2014; 62: 40-44.

[45] CHAN HL, CHIU WC, CHEN VC, HUANG KY, WANG TN et al. SSRIs associated with decreased risk of hepatocellular carcinoma: a population-based case-control study. Psychooncology 2018; 27: 187-192. https://doi.org/10.1002/ pon. 4493

[46] HUANG L, LIN J, XIANG S, ZHAO K, YU J et al. Sunitinib, a clinically used anticancer drug, is a potent AChE inhibitor and attenuates cognitive impairments in mice. ACS Chem Neurosci 2016; 7: 1047-1056. https://doi.org/10.1021/ acschemneuro.5b00329

[47] CHUFFA LGA, REITER RJ, LUPI LA. Melatonin as a promising agent to treat ovarian cancer: molecular mechanisms. Carcinogenesis 2017; 38: 945-952. https://doi.org/10.1093/ carcin/bgx054

[48] YAMAZAKI S, SAKAKIBARA H, TAKEMURA H, YASUDA M, SHIMOI K. Quercetin-3-O-glucronide inhibits noradrenaline binding to $\alpha 2$-adrenergic receptor, thus suppressing DNA damage induced by treatment with 4-hydroxyestradiol and noradrenaline in MCF-10A cells. J Steroid Biochem Mol Biol 2014; 143: 122-129. https://doi. org/10.1016/j.jsbmb.2014.02.014

[49] SUN F, DING XP, AN SM, TANG YB, YANG XJ et al. Adrenergic DNA damage of embryonic pluripotent cells via $\beta 2$ receptor signalling. Sci Rep 2015; 5: 15950. https://doi. org/10.1038/srep 15950 
[50] MUTHALIF MM, BENTER IF, KARZOUN N, FATIMA S, HARPER J et al. 20-Hydroxyeicosatetraenoic acid mediates calcium/calmodulin-dependent protein kinase II-induced mitogen-activated protein kinase activation in vascular smooth muscle cells. Proc Natl Acad Sci U S A 1998; 95: 12701-12706. https://doi.org/10.1073/pnas.95.21.12701

[51] YANAGAWA Y, MATSUMOTO M, TOGASHI H. Enhanced dendritic cell antigen uptake via alpha2 adrenoceptor-mediated PI3K activation following brief exposure to noradrenaline. J Immunol 2010; 185: 5762-5768. https://doi. org/10.4049/jimmunol.1001899

[52] HUANG XY, WANG HC, YUAN Z, HUANG J, ZHENG Q. Norepinephrine stimulates pancreatic cancer cell proliferation, migration and invasion via $\beta$-adrenergic receptordependent activation of P38/MAPK pathway. Hepatogastroenterology 2012; 59: 889-893. https://doi.org/10.5754/ hge11476

[53] GUO K, MA Q, LI J, WANG Z, SHAN T et al. Interaction of the sympathetic nerve with pancreatic cancer cells promotes perineural invasion through the activation of STAT3 signalling. Mol Cancer Ther 2013; 12: 264-273. https://doi. org/10.1158/1535-7163.MCT-12-0809

[54] WILLIS RE. Human gene control by vital oncogenes: revisiting a theoretical model and its implications for targeted cancer therapy. Int J Mol Sci 2012; 13: 316-335. https://doi. org/10.3390/ijms13010316

[55] YASUDA MT, SAKAKIBARA H, SHIMOI K. Estrogen- and stress-induced DNA damage in breast cancer and chemoprevention with dietary flavonoid. Genes Environ 2017; 39: 10. https://doi.org/10.1186/s41021-016-0071-7

[56] MORE SS, ITSARA M, YANG X, GEIER EG, TADANO $\mathrm{MK}$ et al. Vorinostat increases expression of functional norepinephrine transporter in neuroblastoma in vitro and in vivo model systems. Clin Cancer Res 2011; 17: 2339-2349. https://doi.org/10.1158/1078-0432.CCR-10-2949

[57] SLINGERLAND M, GUCHELAAR HJ, GELDERBLOM H. Histone deacetylase inhibitors: an overview of the clinical studies in solid tumors. Anticancer Drugs 2014; 25: 140-149. https://doi.org/10.1097/CAD.0000000000000040

[58] DUVIC M, DIMOPOULOS M. The safety profile of vorinostat (suberoylanilide hydroxamic acid) in hematologic malignancies: A review of clinical studies. Cancer Treat Rev 2016; 43: 58-66. https://doi.org/10.1016/j.ctrv.2015.04.003

[59] HUANG XE, HAMAJIMA N, SAITO T, MATSUO K, MIZUTANI $M$ et al. Possible association of beta2- and beta3-adrenergic receptor gene polymorphisms with susceptibility to breast cancer. Breast Cancer Res 2001; 3: 264-269. https://doi.org/10.1186/bcr304

[60] TAKEZAKI T, HAMAJIMA N, MATSUO K, TANAKA R, HIRAI $\mathrm{T}$ et al. Association of polymorphisms in the beta-2 and beta- 3 adrenoceptor genes with risk of colorectal cancer in Japanese. Int J Clin Oncol 2001; 6: 117-122. https://doi. org/10.1007/pl00012092

[61] BABOL K, PRZYBYLOWSKA K, LUKASZEK M, PERTYNSKI T, BLASIAK J. An association between the Trp64Arg polymorphism in the beta3-adrenergic receptor gene and endometrial cancer and obesity. J Exp Clin Cancer Res 2004; 23: 669-674.
[62] HE RH, HE YJ, TANG YJ, ZHOU HH, MCLEOD HL et al. The potential anticancer effect of beta-blockers and the genetic variations involved in the interindividual difference. Pharmacogenomics 2016; 17: 74-79. https://doi. org/10.2217/pgs.15.152

[63] WALSTON J, LOWE A, SILVER K, YANG Y, BODKIN NL et al. The beta3-adrenergic receptor in the obesity and diabetes prone rhesus monkey is very similar to human and contains arginine at codon 64. Gene 1997; 188: 207-213. https:// doi.org/10.1016/s0378-1119(96)00796-2

[64] MELIS MG, SECCHI G, BRIZZI P, SEVERINO C, MAIOLI $\mathrm{M}$ et al. The Trp64Arg beta3-adrenergic receptor amino acid variant confers increased sensitivity to the pressor effects of noradrenaline in Sardinian subjects. Clin Sci (Lond) 2002; 103: 397-402. https://doi.org/10.1042/cs1030397

[65] MASUO K, KATSUYA T, FU Y, RAKUGI H, OGIHARA $\mathrm{T}$ et al. Beta2-adrenoceptor polymorphisms relate to insulin resistance and sympathetic overactivity as early markers of metabolic disease in nonobese, normotensive individuals. Am J Hypertens 2005; 18: 1009-1014. https://doi. org/10.1016/j.amjhyper.2005.01.006

[66] ABE M, WU Z, YAMAMOTO M, JIN JJ, TABARA Y et al. Association of dopamine beta-hydroxylase polymorphism with hypertension through interaction with fasting plasma glucose in Japanese. Hypertens Res 2005; 28: 215-221. https://doi.org/10.1291/hypres.28.215

[67] RADISAUSKAS R, KUZMICKIENE I, MILINAVICIENE E, EVERATT R. Hypertension, serum lipids and cancer risk: A review of epidemiological evidence. Medicina (Kaunas) 2016; 52: 89-98. https://doi.org/10.1016/j.medici.2016.03.002

[68] TAKEICHI N, BA D, KOGA Y, KOBAYASHI H. Immunologic suppression of carcinogenesis in spontaneously hypertensive rats (SHR) with T cell depression. J Immunol 1983; 130: 501-505.

[69] UEDA N, KONDO M. Chromosome aberrations induced by 7,12-dimethylbenz[a]-anthracene in bone marrow cells of spontaneously hypertensive rats (SHR) and control Wistar Kyoto (WKY) rats: time course and site specificity. J Natl Cancer Inst 1984; 73: 525-530. https://doi.org/10.1093/ jnci/73.2.525

[70] LIANG Z, XIE B, LI J, WANG X, WANG S et al. Hypertension and risk of prostate cancer: a systematic review and meta-analysis. Sci Rep 2016; 6: 31358. https://doi.org/10.1038/ srep31358

[71] SUN LM, KUO HT, JENG LB, LIN CL, LIANG JA et al. Hypertension and subsequent genitourinary and gynecologic cancers risk: a population-based cohort study. Medicine (Baltimore) 2015; 94: e753. https://doi.org/10.1097/ MD.0000000000000753

[72] SOLT VB, BROWN MR, KENNEDY B, KOLTERMAN OG, ZIEGLER MG. Elevated insulin, norepinephrine, and neuropeptide Y in hypertension. Am J Hypertens 1990; 3: 823-828. https://doi.org/10.1093/ajh/3.11.823

[73] BENARROCH EE. Physiology and pathophysiology of the autonomic nervous system. Continuum (Minneap Minn) 2020; 26: 12-24. https://doi.org/10.1212/ CON.0000000000000817 
[74] SOUDANI NY, FAKHOURY RM, KAISSI SS, ZGHEIB NK. The role of genetic polymorphisms in endothelial nitric oxide synthase and beta2-adrenergic receptors with risk of hypertension in a sample of Lebanese people. Saudi Med J 2014; 35: 255-260.

[75] JABLONSKIS LT, HOWE PR. Elevated plasma adrenaline in spontaneously hypertensive rats. Blood Press 1994; 3: 106111. https://doi.org/10.3109/08037059409101529

[76] DIGNE-MALCOLM H, FRISE MC, DORRINGTON KL. How Do Antihypertensive Drugs Work? Insights from Studies of the Renal Regulation of Arterial Blood Pressure. Front Physiol 2016; 7: 320. https://doi.org/10.3389/ fphys.2016.00320

[77] KIM H, GIOVANNUCCI EL. Sex differences in the association of obesity and colorectal cancer risk. Cancer Causes Control 2017; 28: 1-4. https://doi.org/10.1007/s10552-0160831-5

[78] VIDAL AC, FREEDLAND SJ. Obesity and Prostate Cancer: A Focused Update on Active Surveillance, Race, and Molecular Subtyping. Eur Urol 2017; 72: 78-83. https://doi. org/10.1016/j.eururo.2016.10.011

[79] ARNOLD M, FREISLING H, STOLZENBERG-SOLOMON $\mathrm{R}$, KEE F, O'DOHERTY MG et al. Overweight duration in older adults and cancer risk: a study of cohorts in Europe and the United States. Eur J Epidemiol 2016; 31: 893-904. https:// doi.org/10.1007/s10654-016-0169-Z

[80] TUCK ML. Obesity, the sympathetic nervous system, and essential hypertension. Hypertension 1992; 19: I67-77. https:// doi.org/10.1161/01.hyp.19.1_suppl.i67

[81] FELDMAN JM, BLALOCK JA, ZERN RT. Elevated hypothalamic norepinephrine content in mice with the hereditary obese-hyperglycemic syndrome. Horm Res 1979; 11: 170-178. https://doi.org/10.1159/000179052

[82] MASUO K, KATSUYA T, FU Y, RAKUGI H, OGIHARA T et al. Beta2- and beta3-adrenergic receptor polymorphisms are related to the onset of weight gain and blood pressure elevation over 5 years. Circulation 2005; 111: 3429-3434. https://doi.org/10.1161/CIRCULATIONAHA.104.519652

[83] YOUNG JB, DALY PA, UEMURA K, CHAOULOFF F. Effects of chronic lard feeding on sympathetic nervous system activity in the rat. Am J Physiol 1994; 267: R1320-1328. https://doi.org/10.1152/ajpregu.1994.267.5.R1320

[84] MCCULLOUGH AJ. Epidemiology of the metabolic syndrome in the USA. J Dig Dis 2011; 12: 333-340. https://doi. org/10.1111/j.1751-2980.2010.00469.x

[85] NESTEL PJ, KHAN AA, STRAZNICKY NE, MELLETT NA, JAYAWARDANA $K$ et al. Markers of sympathetic nervous system activity associate with complex plasma lipids in metabolic syndrome subjects. Atherosclerosis 2017; 256: 21-28. https://doi.org/10.1016/j.atherosclerosis.2016.11.032

[86] MEIKLE PJ, CHRISTOPHER MJ. Lipidomics is providing new insight into the metabolic syndrome and its sequelae. Curr Opin Lipidol 2011; 22: 210-215. https://doi. org/10.1097/MOL.0b013e3283453dbe
[87] RORSMAN P, BOKVIST K, AMMALA C, ARKHAMMAR P, BERGGREN PO et al. Activation by adrenaline of a lowconductance $\mathrm{G}$ protein-dependent $\mathrm{K}+$ channel in mouse pancreatic B cells. Nature 1991; 349: 77-79. https://doi. org/10.1038/349077a0

[88] BAIL J, MENESES K, DEMARK-WAHNEFRIED W. Nutritional status and diet in cancer prevention. Semin Oncol Nurs 2016; 32: 206-214. https://doi.org/10.1016/j. soncn.2016.05.004

[89] BOSTICK RM, POTTER JD, KUSHI LH, SELLERS TA, STEINMETZ KA et al. Sugar, meat, and fat intake, and nondietary risk factors for colon cancer incidence in Iowa women (United States). Cancer Causes Control 1994; 5: 38-52. https://doi.org/10.1007/BF01830725

[90] FAVERO A, PARPINEL M, FRANCESCHI S. Diet and risk of breast cancer: major findings from an Italian case-control study. Biomed Pharmacother 1998; 52: 109-115. https://doi. org/10.1016/S0753-3322(98)80088-7

[91] DESTEFANIE, DENEO-PELLEGRINIH, MENDILAHARSU M, RONCO A, CARZOGLIO JC. Dietary sugar and lung cancer: a case-control study in Uruguay. Nutr Cancer 1998; 31: 132-137. https://doi.org/10.1080/01635589809514692

[92] MICHAUD DS, LIU S, GIOVANNUCCI E, WILLETT WC, COLDITZ GA et al. Dietary sugar, glycemic load, and pancreatic cancer risk in a prospective study. J Natl Cancer Inst 2002; 94: 1293-1300. https://doi.org/10.1093/jnci/94.17.1293

[93] FRIBERG E, WALLIN A, WOLK A. Sucrose, high-sugar foods, and risk of endometrial cancer--a population-based cohort study. Cancer Epidemiol Biomarkers Prev 2011; 20: 1831-1837. https://doi.org/10.1158/1055-9965.EPI-11-0402

[94] RABEN A, MACDONALD I, ASTRUP A. Replacement of dietary fat by sucrose or starch: effects on $14 \mathrm{~d}$ ad libitum energy intake, energy expenditure and body weight in formerly obese and never-obese subjects. Int J Obes Relat Metab Disord 1997; 21: 846-859. https://doi.org/10.1038/sj.ijo.0800494

[95] YOUNG JB, LANDSBERG L. Stimulation of the sympathetic nervous system during sucrose feeding. Nature 1977; 269: 615-617. https://doi.org/10.1038/269615a0

[96] LEVIN BE, TRISCARI J, SULLIVAN AC. Altered sympathetic activing during development of diet-induced obesity in rat. Am J Physiol 1983; 244: R347-355. https://doi. org/10.1152/ajpregu.1983.244.3.R347

[97] SUZUKI K, SUZUKI K, MITSUOKA T. Effect of low-fat, high-fat, and fiber-supplemented high-fat diets on colon cancer risk factors in feces of healthy subjects. Nutr Cancer 1992; 18: 63-71. https://doi.org/10.1080/01635589209514206

[98] DAY SD, ENOS RT, MCCLELLAN JL, STEINER JL, VELAZQUEZ KT et al. Linking inflammation to tumorigenesis in a mouse model of high-fat-diet-enhanced colon cancer. Cytokine 2013; 64: 454-462. https://doi.org/10.1016/j. cyto.2013.04.031

[99] MATTISSON I, WIRFALT E, WALLSTROM P, GULLBERG B, OLSSON $\mathrm{H}$ et al. High fat and alcohol intakes are risk factors of postmenopausal breast cancer: a prospective study from the Malmö diet and cancer cohort. Int J Cancer 2004; 110: 589-597. https://doi.org/10.1002/ijc.20166 
[100] LOPHATANANON A, ARCHER J, EASTON D, POCOCK $\mathrm{R}$, DEARNALEY D et al. Dietary fat and early-onset prostate cancer risk. Br J Nutr 2010; 103: 1375-1380. https://doi. org/10.1017/S0007114509993291

[101] SCHWARTZ JH, YOUNG JB, LANDSBERG L. Effect of dietary fat on sympathetic nervous system activity in the rat. J Clin Invest 1983; 72: 361-370. https://doi.org/10.1172/ jci110976

[102] LEVIN BE, TRISCARI J, SULLIVAN AC. The effect of diet and chronic obesity on brain catecholamine turnover in the rat. Pharmacol Biochem Behav 1986; 24: 299-304. https:// doi.org/10.1016/0091-3057(86)90354-0

[103] KUNE GA, KUNE S, WATSON LF. Dietary sodium and potassium intake and colorectal cancer risk. Nutr Cancer 1989; 12: 351-359. https://doi.org/10.1080/01635588909514036

[104] TSUGANE S, SASAZUKI S, KOBAYASHI M, SASAKI S. Salt and salted food intake and subsequent risk of gastric cancer among middle-aged Japanese men and women. Br J Cancer 2004; 90: 128-134. https://doi.org/10.1038/ sj.bjc. 6601511

[105] KAWAMURA H, TOMORI H, NARUSE Y, MAKI M, KOMATSU K et al. Dietary sodium concentration modifies catecholamine release with stress in spontaneously hypertensive rats. Nihon Jinzo Gakkai Shi 1991; 33: 873-878.

[106] HOU R, LIU Z, LIU J, LIU W, WANG Z et al. The circadian rhythm of blood pressure and the effect of salt intake in saltsensitive subjects. Chin Med J (Engl) 2000; 113: 22-26.

[107] DIELI-CONWRIGHT CM, LEE K, KIWATA JL. Reducing the Risk of Breast Cancer Recurrence: an Evaluation of the Effects and Mechanisms of Diet and Exercise. Curr Breast Cancer Rep 2016; 8: 139-150. https://doi.org/10.1007/ s12609-016-0218-3

[108] LIU L, SHI Y, LI T, QIN Q, YIN J et al. Leisure time physical activity and cancer risk: evaluation of the WHO's recommendation based on 126 high-quality epidemiological studies. $\mathrm{Br}$ J Sports Med 2016; 50: 372-328. https://doi.org/10.1136/bjsports-2015-094728

[109] EMAUS A, THUNE I. Physical activity and lung cancer prevention. Recent Results Cancer Res 2011; 186: 101-133. https://doi.org/10.1007/978-3-642-04231-7_5

[110] DIMITROV S, HULTENG E, HONG S. Inflammation and exercise: Inhibition of monocytic intracellular TNF production by acute exercise via $\beta 2$-adrenergic activation. Brain Behav Immun 2017; 61: 60-68. https://doi.org/10.1016/j. bbi.2016.12.017

[111] JEZOVA D, VIGAS M, TATAR P, KVETNANSKY R, NAZAR $\mathrm{K}$ et al. Plasma testosterone and catecholamine responses to physical exercise of different intensities in men. Eur J Appl Physiol Occup Physiol 1985; 54: 62-66. https:// doi.org/10.1007/BF00426300

[112] IKEDA T, GOMI T, SASAKI Y. Effects of swim training on blood pressure, catecholamines and prostaglandins in spontaneously hypertensive rats. Jpn Heart J 1994; 35: 205-211. https://doi.org/10.1536/ihj.35.205

[113] CHEN HI, LIT HT, CHEN CC. Physical conditioning decreases norepinephrine-induced vasoconstriction in rabbits. Possible roles of norepinephrine-evoked endothelium-derived relaxing factor. Circulation 1994; 90: 970-975. https:// doi.org/10.1161/01.cir.90.2.970
[114] GAVA NS, VERAS-SILVA AS, NEGRAO CE, KRIEGER EM. Low-intensity exercise training attenuates cardiac betaadrenergic tone during exercise in spontaneously hypertensive rats. Hypertension 1995; 26: 1129-1133. https://doi. org/10.1161/01.hyp.26.6.1129

[115] HSU YC, CHEN HI, KUO YM, YU L, HUANG TY et al. Chronic treadmill running in normotensive rats resets the resting blood pressure to lower levels by upregulating the hypothalamic GABAergic system. J Hypertens 2011; 29: 23392348. https://doi.org/10.1097/HJH.0b013e32834c628f

[116] GRASSI G, SERAVALLE G, CALHOUN DA, MANCIA G. Physical training and baroreceptor control of sympathetic nerve activity in humans. Hypertension 1994; 23: 294-301. https://doi.org/10.1161/01.hyp.23.3.294

[117] SEITZ HK, CHO CH. Contribution of alcohol and tobacco use in gastrointestinal cancer development. Methods Mol Biol 2009; 472: 217-241. https://doi.org/10.1007/978-160327-492-0_9

[118] SHAKERI R, KAMANGAR F, MOHAMADNEJAD M, TABRIZI R, ZAMANI F et al. Opium use, cigarette smoking, and alcohol consumption in relation to pancreatic cancer. Medicine (Baltimore) 2016; 95: e3922. https://doi. org/10.1097/MD.0000000000003922

[119] PETTI S, MASOOD M, SCULLY C. The magnitude of tobacco smoking-betel quid chewing-alcohol drinking interaction effect on oral cancer in South-East Asia. A meta-analysis of observational studies. PLoS One 2013; 8: e78999. https:// doi.org/10.1371/journal.pone.0078999

[120] FITZGERALD PJ. Elevated Norepinephrine may be a Unifying Etiological Factor in the Abuse of a Broad Range of Substances: Alcohol, Nicotine, Marijuana, Heroin, Cocaine, and Caffeine. Subst Abuse 2013; 7: 171-183. https://doi. org/10.4137/SART.S13019

[121] SCHOEMAKER MJ, JONES ME, WRIGHT LB, GRIFFIN J, MCFADDEN E et al. Psychological stress, adverse life events and breast cancer incidence: a cohort investigation in 106,000 women in the United Kingdom. Breast Cancer Res 2016; 18: 72. https://doi.org/10.1186/s13058-016-0733-1

[122] YEH ML, LEE TY. A Prospective Study of the Relationship between Psychological Factors and Breast Cancer. Asia Pac J Oncol Nurs 2016; 3: 170-175. https://doi.org/10.4103/23475625.170223

[123] LI P, HUANG J, WU H, FU C, LI Y et al. Impact of lifestyle and psychological stress on the development of early onset breast cancer. Medicine (Baltimore) 2016c; 95: e5529. https://doi.org/10.1097/MD.0000000000005529

[124] FISCHER A, ZIOGAS A, ANTON-CUlVER H. Perception matters: stressful life events increase breast cancer risk. J Psychosom Res 2018; 110: 46-53. https://doi.org/10.1016/j. jpsychores.2018.03.010

[125] BATTY GD, RUSS TC, STAMATAKIS E, KIVIMAKIM. Psychological distress in relation to site specific cancer mortality: pooling of unpublished data from 16 prospective cohort studies. BMJ 2017; 356: j108. https://doi.org/10.1136/bmj.j108

[126] BLANC-LAPIERRE A, ROUSSEAU MC, WEISS D, ELZEIN M, SIEMIATYCKI J et al. Lifetime report of perceived stress at work and cancer among men: A case-control study in Montreal, Canada. Prev Med 2016; 96: 28-35. https://doi. org/10.1016/j.ypmed.2016.12.004 
[127] FENG Z, LIU L, ZHANG C, ZHENG T, WANG J et al. Chronic restraint stress attenuates p53 function and promotes tumorigenesis. Proc Natl Acad Sci USA 2012; 109: 7013-7018. https://doi.org/10.1073/pnas.1203930109

[128] HASSAN S, KARPOVA Y, BAIZ D, YANCEY D, PULLIKUTH A et al. Behavioral stress accelerates prostate cancer development in mice. J Clin Invest 2013; 123: 874-886. https://doi.org/10.1172/JCI63324

[129] ADAMEKOVA E, MARKOVA M, KUBATKA P, BOJKOVA $\mathrm{B}, \mathrm{AHLERS}$ I et al. NMU-induced mammary carcinogenesis in female rats is influenced by repeated psychoemotional stress. Neoplasma 2003; 50: 428-432.

[130] MUSSO NR, BRENCI S, SETTI M, INDIVERI F, LOTTI G. Catecholamine content and in vitro catecholamine synthesis in peripheral human lymphocytes. J Clin Endocrinol Metab 1996; 81: 3553-3557. https://doi.org/10.1210/ jcem.81.10.8855800

[131] BERGQUIST J, SILBERRING J. Identification of catecholamines in the immune system by electrospray ionization mass spectrometry. Rapid Commun Mass Spectrom 1998; 12: 683-688. https://doi.org/10.1002/(SICI)10970231(19980615)12:11<683::AID-RCM218>3.0.CO;2-N

[132] AL-WADEI MH, AL-WADEI HA, SCHULLER HM. Pancreatic cancer cells and normal pancreatic duct epithelial cells express an autocrine catecholamine loop that is activated by nicotinic acetylcholine receptors $\alpha 3, \alpha 5$, and $\alpha 7$. Mol Cancer Res 2012; 10: 239-249. https://doi.org/10.1158/15417786.MCR-11-0332

[133] AL-WADEI HAN, AL-WADEI MH, SCHULLER HM. Cooperative regulation of non-small cell lung carcinoma by nicotinic and beta-adrenergic receptors: a novel target for intervention. PLoS One 2012; 7: e29915. https://doi.org/10.1371/ journal.pone.0029915

[134] BANDALA C, AVILA-LUNA A, GOMEZ-LOPEZ M, ESTRADA-VILLASENOR E, MONTES S et al. Catecholamine levels and gene expression of their receptors in tissues of adults with osteosarcoma. Arch Physiol Biochem 2019; 10: 1-7. https://doi.org/10.1080/13813455.2019.1638942

[135] ZUR HAUSEN H. Cancers in Humans: A Lifelong Search for Contributions of Infectious Agents, Autobiographic Notes. Annu Rev Virol 2019; 6: 1-28. https://doi.org/10.1146/annurev-virology-092818-015907

[136] NGUYEN LV, TA QV, DANG TB, NGUYEN PH, NGUYEN $\mathrm{T}$ et al. Carvedilol improves glucose tolerance and insulin sensitivity in treatment of adrenergic overdrive in high fat diet-induced obesity in mice. PLoS One 2019; 14: e0224674. https://doi.org/10.1371/journal.pone.0224674
[137] MARKETOU M, GUPTA Y, JAIN S, VARDAS P. Differential Metabolic Effects of Beta-Blockers: an Updated Systematic Review of Nebivolol. Curr Hypertens Rep 2017; 19: 22. https://doi.org/10.1007/s11906-017-0716-3

[138] ALVES-WAGNER AB, MORI RC, SABINO-SILVA R, FATIMA LA, DA SILVA ALVEZ A et al. Beta-adrenergic blockade increases GLUT4 and improves glycemic control in insulin-treated diabetic Wistar rats. Auton Neurosci 2015; 193: 108-116. https://doi.org/10.1016/j.autneu.2015.10.003

[139] KANG F, MA W, MA X, SHAO Y, YANG W et al. Propranolol inhibits glucose metabolism and 18F-FDG uptake of breast cancer through posttranscriptional downregulation of hexokinase-2. J Nucl Med 2014; 55: 439-445. https://doi. org/10.2967/jnumed.113.121327

[140] ZANQUETTA MM, NASCIMENTO MEC, MORI RC, D'AGORD SCHAAN B, YOUNG ME et al. Participation of beta-adrenergic activity in modulation of GLUT4 expression during fasting and refeeding in rats. Metabolism 2006; 55: 1538-1545. https://doi.org/10.1016/j.metabol.2006.06.026

[141] AMIN S, LUX A, O'CALLAGHAN F. The journey of metformin from glycaemic control to mTOR inhibition and the suppression of tumour growth. Br J Clin Pharmacol 2019; 85: 37-46. https://doi.org/10.1111/bcp.13780

[142] RICO M, BAGLIONI M, BONDARENKO M, LALUCE NC, ROZADOS V et al. Metformin and propranolol combination prevents cancer progression and metastasis in different breast cancer models. Oncotarget 2017; 8: 2874-2889. https://doi.org/10.18632/oncotarget.13760

[143] DIENEL GA, CRUZ NF. Aerobic glycolysis during brain activation: adrenergic regulation and influence of norepinephrine on astrocytic metabolism. J Neurochem 2016; 138: 14-52. https://doi.org/10.1111/jnc.13630

[144] SALAMON S, PODBREGAR E, KUBATKA P, BUSSELBERG D, CAPRNDA $M$ et al. Glucose Metabolism in Cancer and Ischemia: Possible Therapeutic Consequences of the Warburg Effect. Nutr Cancer 2017; 69: 177-183. https://doi. org/10.1080/01635581.2017.1263751

[145] BUCSEK MJ, QIAO G, MACDONALD CR, GIRIDHARAN T, EVANS L et al. $\beta$-adrenergic signaling in mice housed at standard temperatures suppresses an effector phenotype in CD8+ T cells and undermines checkpoint inhibitor therapy. Cancer Res 2017; 77: 5639-5651. https://doi. org/10.1158/0008-5472.CAN-17-0546 